\title{
Influencing factors on the NMP-22 urine assay: an experimental model
}

\author{
Makito Miyake', Steve Goodison', Evan Gomes Giacoia', Wasia Rizwani ${ }^{1}$, Shanti Ross ${ }^{1}$ and Charles J Rosser ${ }^{2 *}$
}

\begin{abstract}
Background: The commercial NMP-22 urine assays for bladder cancer (BCa) detect nuclear mitotic apparatus protein 1 (NUMA1) using monoclonal antibodies. It remains unclear whether these assays are monitoring a tumor antigen or some other phenomenon associated with the disease state. In this study, we investigated the influence of urinary cellular and protein concentration, and hematuria on the performance of the NMP-22 tests in an experimental model.

Methods: Pooled urine from healthy subjects were spiked with varying concentrations of benign (UROtsa) cells, cancer cells (RT4, T24, KU-7 and UM-UC-14), whole blood or serum, prior to analysis with both NMP22 ${ }^{\circledR}$ Bladder Cancer ELISA test and the NMP22 ${ }^{\circledR}$ BladderChek ${ }^{\circledR}$ point-of-care test.

Results: Urines from control subjects were negative for NMP-22. The addition of whole blood at $50 \mathrm{ul} / 10 \mathrm{ml}$, but not serum, resulted in a false-positive result. Furthermore, the addition of a high concentration of benign urothelial cells $\left(10^{6}\right)$ or the cell lysate from these cells $(306 \mu \mathrm{g}$ protein) resulted in a false-positive result. High concentrations of pooled-cancer cells $\left(10^{6}\right)$ or cell lysate $(30.6 \mu \mathrm{g}$ and above) resulted in a positive NMP-22 assay. Concordance between the NMP-22 ELISA assay and the NMP-22 point of care assay was $>90 \%$.

Conclusions: Rather than detecting a specific tumor antigen, urinary NMP-22 assays may be measuring the cellularity or amount of cell turnover that may be introduced into the urine by a variety of conditions, including surface shedding from bladder tumors. The absence of significant urinary cellularity in some cases due to lesion characteristics or the timing of sampling may result in false-negative NMP-2 assays.
\end{abstract}

Keywords: Bladder cancer, Urine, NMP-22

\section{Background}

Non-invasive urine tests for the early detection or postsurgical surveillance of bladder cancer (BCa) are highly desirable for both patient and healthcare system. Currently, voided urinary cytology (VUC) is the most widely used non-invasive urine test, with reported sensitivities ranging from $13-75 \%$ and specificities ranging from $85-$ $100 \%[1,2]$. A couple of single-biomarker urinalysis assays have been developed for use in this context. One is the bladder tumor antigen (BTA) test, which detects urinary complement factor $\mathrm{H}$-related proteins using monoclonal antibodies [3]. Two assay formats, BTA stat $^{\mathrm{TM}}$ and BTA TRAK ${ }^{\mathrm{m}}$ (Polymedco Inc. Cortlandt Manor, NY, USA), are FDA approved for the detection

\footnotetext{
*Correspondence: Charles.rosser@orlandohealth.com

${ }^{2}$ Section of Urologic Oncology, MD Anderson Cancer Center Orlando, $1400 \mathrm{~S}$. Orange Ave, Orlando, FL 32806, USA

Full list of author information is available at the end of the article
}

and surveillance of $\mathrm{BCa}$ in urine samples. For $\mathrm{BCa}$ detection, urinary BTA tests have diagnostic sensitivities ranging from $29-83 \%$ and specificities ranging from $56-86 \%$ $[4,5]$. Recently, Oge et al. demonstrated that hematuria adversely affects the accuracy of BTA assays [6].

Another commercial assay that has been used for $\mathrm{BCa}$ detection in voided urine samples is the nuclear matrix protein-22 (NMP-22) test, which detects the nuclear mitotic apparatus protein 1 (NUMA1), using monoclonal antibodies [7]. Two assay formats, the NMP2 ${ }^{\circledR}$ Bladder Cancer ELISA Test Kit and the NMP22 ${ }^{\circledR}$ BladderChek $^{\circledR}$ point-of-care test (Alere Scarborough, Inc. Waltham, $\mathrm{MA})$, are FDA approved for the detection and surveillance of $\mathrm{BCa}$ in urine samples. For $\mathrm{BCa}$ detection, urinary NMP-22 tests have diagnostic sensitivities ranging from $47-100 \%$ and specificities ranging from $55-98 \%$ $[8,9]$. It remains unclear whether the NMP-22 test is monitoring the increased expression of a bona fide

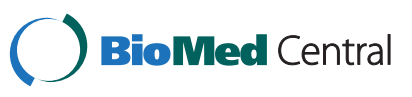


tumor antigen, or some other phenomenon associated with $\mathrm{BCa}$ such as hematuria or urothelial turnover. Noting the limitations of the BTA assays, we investigated the influence of urinary cellular concentration, urinary protein concentration and hematuria on the performance of the NMP-22 tests in an experimental model.

\section{Methods}

\section{Clinical sampling and processing}

Under IRB approval and informed consent, serum samples were collected from 20 men with no previous history of $\mathrm{BCa}$ and 20 men with newly diagnosed $\mathrm{BCa}$. Serum was isolated, snap frozen and stored at $-80^{\circ} \mathrm{C}$ until use. Two hundred $\mathrm{ml}$ of urine and $10 \mathrm{ml}$ of whole blood were collected from three healthy subjects. None of the subjects had any current or history of urological disorder. Microscopic examination of the urine samples showed no cells and all samples were tested by urinary dipstick test for abnormalities. Pertinent clinical information for each subject was recorded.

\section{Cell lines and culture}

Human bladder cancer cell lines; RT4 (ATCC, Manassas, VA), T24 (ATCC, Manassas, VA), UM-UC-14 (a generous gift from Dr. H. Bart Grossman, The University of Texas M.D. Anderson Cancer Center, Houston, TX), and KU-7 (a generous gift from Dr. Motoyoshi Tanaka, Nara University Medical School, Nara, Japan) were available for analysis. The benign human bladder cell line, UROtsa, was a generous gift from Dr. Donald Sens at the University Of North Dakota School Of Medicine (Grand Forks, ND). T24, UM-UC-14 and KU-7 cell lines were maintained in RPMI1640 media. UROtsa and RT4 cells were maintained in low-glucose DMEM and McCoy's 5A medium (Life Technologies, Inc., Gaithersburg, MD), respectively. All media were supplemented with $10 \%$ fetal bovine serum, 100 units $/ \mathrm{ml}$ of penicillin and $100 \mu \mathrm{g} / \mathrm{ml}$ of streptomycin. All cells were incubated at $37^{\circ} \mathrm{C}$ in a humidified atmosphere of $5 \% \mathrm{CO}_{2}$ in air.

\section{Experimental model}

To create the experiment model, $200 \mathrm{ml}$ of freshly voided urine samples from three healthy controls were collected in sterile containers. All subjects' urines tested negative for NMP-22 using both the NMP22 ${ }^{\circledR}$ Bladderchek ${ }^{\circledR}$ test and the NMP22 ${ }^{\circledR}$ ELISA kit assay. The urine samples from the three subjects were pooled, mixed and distributed into $10 \mathrm{ml}$ aliquots in $15 \mathrm{ml}$ centrifuge tubes. The human bladder cell lines were washed, trypsinized and counted. For UROtsa, $1 \times 10^{4}$ (low concentration), $1 \times 10^{5}$ (medium concentration) and $1 \times 10^{6}$ (high concentration) cells were each added to triplicate $10 \mathrm{ml}$ pooled urine samples. Equal numbers of RT4, T24, UM-UC-14 and KU-7 were pooled, and $1 \times 10^{4}$ (low concentration), $1 \times 10^{5}$ (medium concentration) and $1 \times 10^{6}$ (high concentration) cells were added to triplicate $10 \mathrm{ml}$ pooled urine aliquots. For cell lysate analyses, $1 \times$ $10^{6}$ cells of each cell line were lysed by RIPA buffer (Pierce, Rockford, IL) and total protein concentration measured. The total proteins extracted from $1 \times 10^{6}$ cells of UROtsa, RT4, T24, UM-UC-14 and KU-7 were 431ug, 369ug, 174ug, 261ug and $293 \mu \mathrm{g}$, respectively, with a mean total protein extract of $306 \mu \mathrm{g}$. In the following experiments, $3.06 \mu \mathrm{g}, 30.6 \mu \mathrm{g}$ and $306 \mu \mathrm{g}$ of cellular proteins corresponding to $1 \times 10^{4}$ (low concentration), $1 \times$ $10^{5}$ (medium concentration) and $1 \times 10^{6}$ (high concentration) cells, were used. These UROtsa lysates and pooled cancer cell lysates were added to pooled urine samples in triplicate. To monitor hematuria influence, pooled whole blood $(1,5,20$ and $50 \mu \mathrm{l})$ from 20 subjects with and 20 subjects without $\mathrm{BCa}$ was added analyzed in triplicate in $10 \mathrm{ml}$ urine samples. Serum samples from 20 subjects with and 20 subjects without BCa were pooled. Serum protein concentrations similar to the cellular lysate concentrations, $3.06 \mu \mathrm{g}$ (low concentration), $30.6 \mu \mathrm{g}$ (medium concentration) and $306 \mu \mathrm{g}$ (high concentration) were added to triplicate pooled urine samples. Figure 1 illustrates the experimental model.

\section{Reagents and tests}

The NMP-22 assays: NMP22 ${ }^{\circledR}$ BladderChek Test ${ }^{\circledR}$ and NMP2 ${ }^{\circledR}$ Bladder Cancer ELISA Test Kit were purchased from Alere Scarborough, Inc. (Waltham, MA). The NMP2 $2{ }^{\circledR}$ Bladderchek Test ${ }^{\circledR}$ was performed by adding 4 drops of urine into the well of a disposable test device for all urine samples. Results were considered to be positive if any band, no matter how faint, appeared in the test zone $30 \mathrm{~min}$ after adding the urine to the well. The NMP-22 ELISA assay was conducted according to the manufacturer's instructions. Briefly, $200 \mu \mathrm{l}$ of urine was added to the 96-well plate. Calibration curves were prepared using purified standards for each protein assessed. Curve fitting was accomplished by linear regression following manufacturer's instructions. Based on published literature, a cutoff value of $10 \mathrm{U} / \mathrm{mL}$ was used to define a positive NMP-22 ELISA assay $[8,10]$. Urinalysis was performed with MULTISTIX PRO Reagent Strips (Bayer HealthCare, Elkhart, IN) to assess protein. In addition, urinary protein concentration was determined using Pierce 660-nm Protein Assay Kit (Thermo Fisher Scientific Inc., Waltham, MA, USA).

\section{Data analysis}

A Student $t$-test was used to compare NMP-22 expression levels in cell lines. Statistical significance in this study was set at $p<0.05$ and all reported $p$ values were 2 -sided. All analyses were performed with PRISM software version 5.00 (GraphPad Software, San Diego, CA). 




\section{Results}

The NMP2 ${ }^{\circledR}$ Bladder Cancer ELISA Test was performed on a panel of human bladder cell lines (Figure 2). The cancer cell lines, RT4, T24 and UM-UC-14, had significantly higher NMP-22 levels than the benign cell line, UROtsa $(p<0.05)$. One bladder cancer cell line, KU-7, did not express higher NMP-22 levels than UROtsa. The NMP-22 level recorded for a pool of the four cancer cell lines was significantly higher than the NMP-22 level of UROtsa $(24,299 \pm 2,110 \mathrm{U} / \mathrm{mg}$ vs. $12,641 \pm 1,973 \mathrm{U} / \mathrm{mg}, p<0.05)$.

The results from applying both the NMP22 ${ }^{\circledR}$ Bladder Cancer ELISA Test and the NMP22 ${ }^{\circledR}$ Bladdercheck $^{\circledR}$ Test on samples taken from our experimental model are described in Table 1 and Figure 3. Urine samples from

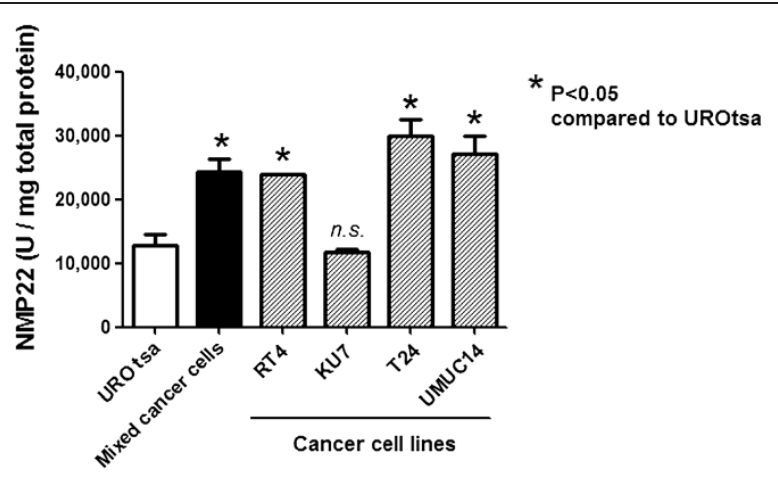

Figure 2 NMP-22 ELISA assay of human bladder cell lines. The human bladder cancer cell lines, RT4, T24 and UM-UC-14 had elevated NMP-22 levels compared to the benign UROtsa human cell line. Levels of NMP-22 in the KU-7 human bladder cancer cell line were not elevated compared to UROtsa. Significance $(p<0.05)$ was assessed by Student $t$ test. n.s., not significant.

Individual subjects, and a pool of those samples were negative for NMP-22. Whole cells or cell lysates of the cancer cell line pool and UROtsa cells were added to the pooled urine sample and re-analyzed using both NMP22 ELISA tests. Only the high concentration $\left(1 \times 10^{6}\right)$ of UROtsa or pooled cancer cells produced a positive NMP-22 test. Cellular lysates from $1 \times 10^{5}$ and $1 \times 10^{6}$ pooled cancer cells, and from $1 \times 10^{6}$ UROtsa cells produced a positive result. The only discordance seen between the NMP22 ${ }^{\circledR}$ Bladder Cancer ELISA Test and the NMP22 ${ }^{\circledR}$ Bladdercheck $^{\circledR}$ test was seen when UROtsa lysate $\left(1 \times 10^{5}\right.$ cells $)$ produced a positive NMP $22^{\circledR}$ Bladdercheck ${ }^{\circledR}$ test but a negative NMP-22 ELISA assay.

The addition of whole blood at $5 \mathrm{ul}$ and $20 \mathrm{ul}$ per $10 \mathrm{ml}$ of urine did not cause a positive NMP-22 result, but spiking $50 \mu \mathrm{l} / 10 \mathrm{ml}$ did produce false-positive NMP-22 assays. The fact that the false-positive effect was cellular was confirmed by the addition of pooled serum samples obtained from subjects with or without BCa. Neither serum sample caused NMP-22 test positivity, even at the highest level of 306 ug of protein. Overall, the concordance rates between the NMP2 $2^{\circledR}$ Bladdercheck ${ }^{\circledR}$ test and the NMP $22^{\circledR}$ ELISA kit assay was $>90 \%$ throughout the analyses.

\section{Discussion}

Using a novel experimental model, we evaluated a number of factors that may influence the NMP-22 urine tests. Although the model does not mimic the actual physiological situation exactly, the aim was to test whether the NMP-22 analyte could originate from blood (serum or whole blood) or benign cells of urothelial origin. Previous studies have investigated the influence of blood in the NMP-22 assay. Atsu et al. reported that when whole blood was added to a urine sample, positive NMP-22 results increased in parallel with the increase in 
Table 1 Results of NMP22 ${ }^{\circledR}$ Bladdercheck ${ }^{\circledR}$ Test

\begin{tabular}{|c|c|c|}
\hline Whole cells* & & Assay results \\
\hline \multicolumn{3}{|l|}{ UROtsa } \\
\hline & $10^{4}$ cells & - \\
\hline & $10^{5} \mathrm{cells}$ & - \\
\hline & $10^{6}$ cells & + \\
\hline \multicolumn{3}{|c|}{ Pooled cancer cells } \\
\hline & $10^{4}$ cells & - \\
\hline & $10^{5}$ cells & - \\
\hline & $10^{6}$ cells & + \\
\hline \multicolumn{3}{|l|}{ Cell Lysate* } \\
\hline \multicolumn{3}{|l|}{ UROtsa } \\
\hline & $3.06 \mu \mathrm{g}$ & - \\
\hline & $30.6 \mu \mathrm{g}$ & - \\
\hline & $306 \mu \mathrm{g}$ & + \\
\hline \multicolumn{3}{|c|}{ Pooled cancer cells } \\
\hline & $3.06 \mu \mathrm{g}$ & - \\
\hline & $30.6 \mu \mathrm{g}$ & + \\
\hline & $306 \mu \mathrm{g}$ & + \\
\hline \multicolumn{3}{|l|}{ Serum* } \\
\hline \multicolumn{3}{|l|}{$\mathrm{BCa}$} \\
\hline & $3.06 \mu \mathrm{g}$ & - \\
\hline & $30.6 \mu \mathrm{g}$ & - \\
\hline & $306 \mu \mathrm{g}$ & - \\
\hline \multicolumn{3}{|c|}{ Non-BCa } \\
\hline & $3.06 \mu \mathrm{g}$ & - \\
\hline & $30.6 \mu \mathrm{g}$ & - \\
\hline & $306 \mu \mathrm{g}$ & - \\
\hline \multicolumn{3}{|l|}{ Whole blood* } \\
\hline \multicolumn{3}{|l|}{$\mathrm{BCa}$} \\
\hline & $5 \mu l$ & - \\
\hline & $20 \mu \mathrm{l}$ & - \\
\hline & $50 \mu \mathrm{l}$ & + \\
\hline \multicolumn{3}{|c|}{ Non-BCa } \\
\hline & $5 \mu l$ & - \\
\hline & $20 \mu \mathrm{l}$ & - \\
\hline & $50 \mu \mathrm{l}$ & + \\
\hline
\end{tabular}

*, added to $10 \mathrm{~mL}$ of pooled urine from healthy controls and analyzed; $\mathrm{BCa}$, Bladder cancer.

the amount of red blood cells in the sediment. In addition, the leukocyte count in the urine sediment also had a significant impact, and the investigators concluded that pyuria and hematuria significantly affected urinary NMP-22 [11]. In our study, the influence of blood was confirmed, but we also showed that spiking with intact, benign or cancerous cells caused a positive NMP-22. As expected, cellular lysate from those cells had a greater effect.

NMP-22 (nuclear matrix protein-22) is also known as nuclear mitotic apparatus protein (NUMA or NUMA-1) $[12,13]$. The function of NUMA-1 is to provide structural support for the nucleus and to ensure the correct separation of genetic material during mitosis into the respective daughter cells through mitotic spindle stabilization [14]. To see how NUMA-1 is distributed in healthy and diseased tissues we queried the Human protein Atlas (http://www. proteinatlas.org). The Atlas provides immunohistochemistry data, and expression is confirmed in the majority of cases using 2 or more antibodies for the same antigen [15]. NUMA-1 expression data is available on a wide range of tissues, including both normal and diseased urinary bladder tissue. An overview of the staining patterns across tissues confirms that NUMA-1 is expressed in all tissues with an epithelial component, but also in glandular cells, cells of the lymph node and macrophages. Notably, it is apparent that the normal urothelial lining of the bladder expresses NUMA-1 at a high level (Figure 4). As reported previously, NUMA-1 is localized to the nucleus primarily, but there is granular cytoplasmic staining of NUMA-1 protein also. Carcinoma tissues typically have NUMA-1 expression across the tumor, with some expected heterogeneity, but intensity of staining is often less than that seen in the normal urothelia (Figure 4), and the cytoplasmic component is less pronounced. The imunohistochemistry data suggest that at the interface between urine and bladder lining, the cellular expression level will be at least as strong in normal tissue as in tumor tissue.

We also queried public databases for transcriptome profile data. NUMA-1 expression is reported to be increased in tumors of a variety of tissues, but given the epithelial expression profile of NUMA-1 this can be misleading unless the details of how the cellular composition of solid tissue specimens was corrected for in specific studies are known. However, of note, the profile databases do report that NUMA-1 mRNA is high in whole blood. This is of interest because blood incursion into the bladder can create difficulties in interpretation of urine tests for bladder cancer. We showed in our experimental model that spiking of NMP-22 negative urine with whole blood can cause a false-positive result.

If the NMP-22 test is measuring a nuclear protein that is present in the majority of cell types throughout the body, and one that is particularly prevalent in the normal bladder lining, how does the test perform reasonably well for the detection of BCa. The test could be detecting NMP-22 that is introduced into the urine by hematuria, and since hematuria is the most associated symptom of bladder cancer, then the test would perform no better than a test for hemoglobin as long as the threshold and sensitivity of the two assays were comparable. Conversely, measuring NMP22 introduced by bleeding would impact the sensitivity of the test, calling falsely positive cases that had hematuria through non-malignant causes such as infection or trauma. Alternatively, perhaps the NMP-22 test is a measure of the release and lysis of urothelial cells into the urine. Bladder 


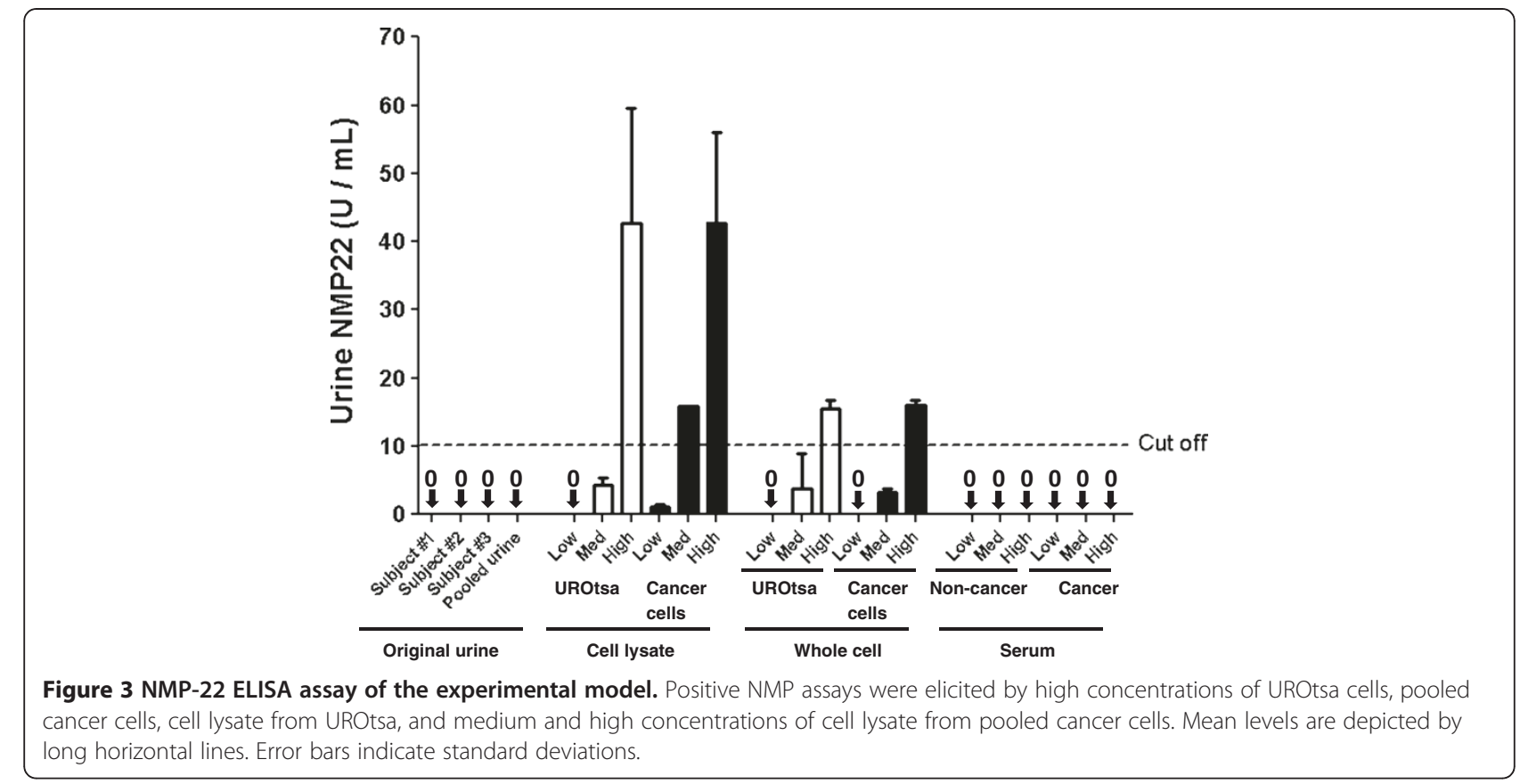

tumors are often friable and shed large numbers of tumor cells into the urine relative to the normal turnover of healthy urothelia. The total number of urothelia shed per unit of time will be greater if the patient has a bladder lesion. NMP-22 is a nuclear scaffold protein and is not known to be secreted, thus, cell lysis must occur for the NMP-22 test to detect soluble protein. If cell lysis occurs at a constant rate, then the increased number of cells released into the urine in the presence of a lesion may suffice for a test, but it is also possible that tumor cells lyse in urine more readily than normal urothelia, thereby amplifying the test to some extent. A likely scenario is that a combination of these factors (more cells released and lysed, and the presence of blood) contribute to the NMP-22 test result. As long as the test outperforms VUC, one can argue that it has value, but identifying what any bladder cancer test is actually measuring would seem to be pertinent and should enable improvement of a given test, or provide insight into how best to combine multiple markers.

Other investigators have associated false-positive NMP22 tests with instrumentation of the genitourinary tract and inflammation [16] and grade of urinary hematuria [17]. Specifically, Huber et al. reported from a large prospective screening study that NMP-22 outcomes are

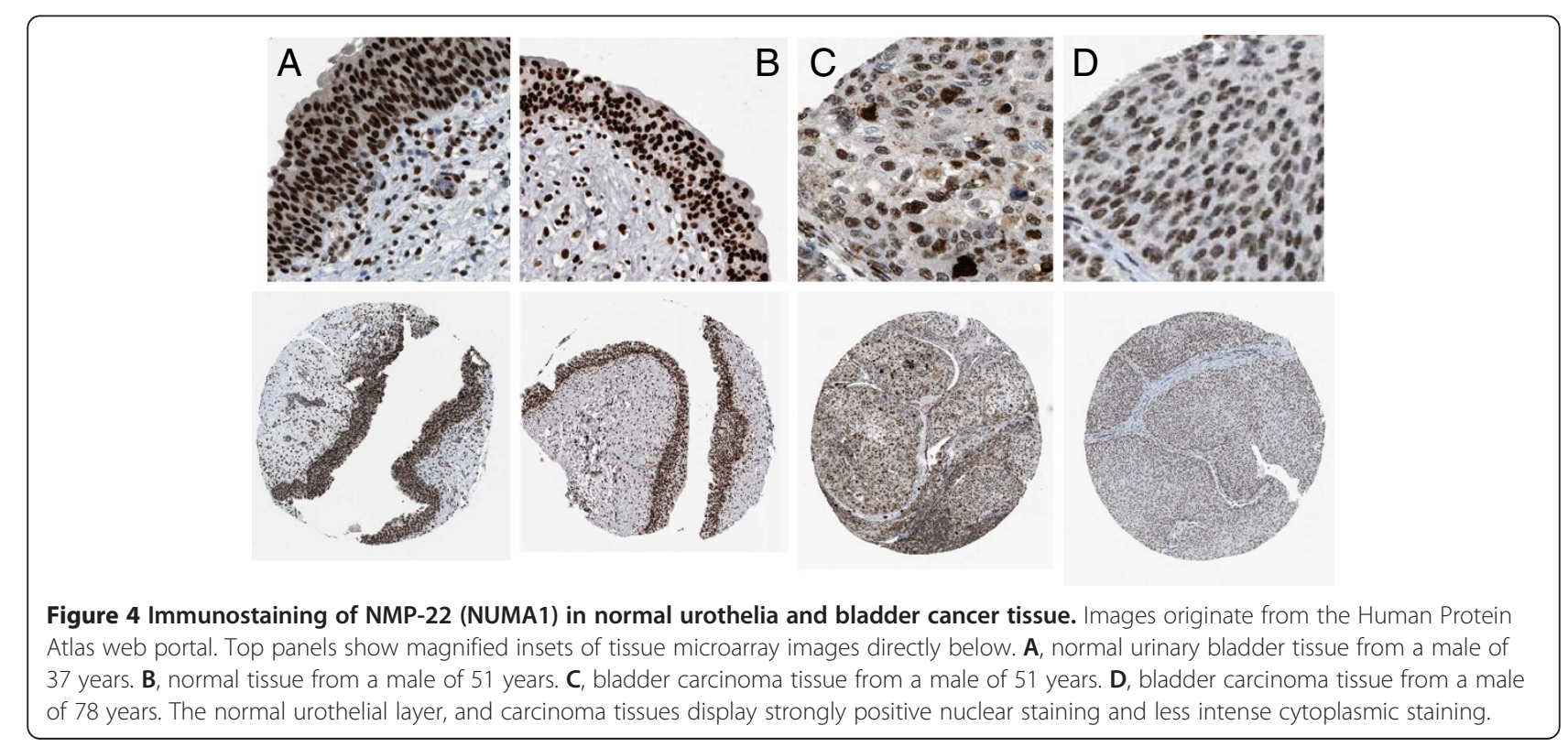


affected by gross hematuria, urinary tract infections and concentrated urine (creatinine $>2.5 \mathrm{~g} / \mathrm{L}$ ) [18]. Furthermore, impaired renal function (i.e., reduced glomerular filtration rate) has been linked to false-positive NMP-22 results, while proteinuria associated with impaired renal function is associated with reduction in urinary cytology specificity [19]. Similar to other urine-based assays, NMP22 has a disappointingly low sensitivity for small, lowgrade tumors [20]. Based on our results we believe the reduced sensitivity is related to low tumor burden and consequent low cell turnover. Perhaps if NMP-22 urinary protein was normalized to total urinary proteins, or to urinary creatinine, then a NMP-22 assay may be better able to diagnose these small, low-grade tumors, which are the most common, yet least threatening of the tumors.

\section{Conclusions}

In combination, these findings raise the question of whether the NMP-22 tests are detecting a bona fide tumor antigen in urine samples or detecting a surrogate for cellularity/cell turnover or hematuria introduced into the urine by a friable bladder tumor. The absence of significant urinary cellularity in subjects with BCa may result in false-negative NMP-22 assays.

\section{Abbreviations}

NMP-22: Nuclear matrix protein 22; NUMA1: Nuclear mitotic apparatus protein 1; BCa: Bladder cancer; VUC: Voided urinary cytology; BTA: Bladder tumor antigen; ELISA: Enzyme-linked immunosorbent assay.

\section{Competing interests}

The authors declare that they have no competing interests.

\section{Authors' contributions}

MM Study concept and design, acquisition of data, data analysis, drafting of manuscript. SG Study concept and design, drafting of manuscript, supervision. EGG acquisition of data and data analysis. WR acquisition of data and data analysis. SR acquisition of data and data analysis. CJR Study concept and design, drafting of manuscript, supervision. All authors have read and approved the final manuscript.

\section{Acknowledgements}

This work was supported by research grants from the Florida Department of Health James and Esther King Team Science Award 10KT-01 (CJR), the National Cancer Institute RO1 CA116161 (SG), and the Flight Attendant Medical Research Institute (CJR).

\section{Author details}

${ }^{1}$ Cancer Research Institute, MD Anderson Cancer Center Orlando, Orlando, FL 32827, USA. ${ }^{2}$ Section of Urologic Oncology, MD Anderson Cancer Center Orlando, 1400 S. Orange Ave, Orlando, FL 32806, USA.

Received: 12 June 2012 Accepted: 9 August 2012

Published: 28 August 2012

\section{References}

1. Rife CC, Farrow GM, Utz DC: Urine cytology of transitional cell neoplasms. Urol Clin North Am 1979, 6:599-612.

2. van Rhijn BW, van der Poel HG, van der Kwast $\mathrm{TH}$ : Urine markers for bladder cancer surveillance: a systematic review. Eur Urol 2005, 47(6):736-48. Epub 2005 Mar 23.

3. Kinders $\mathrm{R}$, Jones $\mathrm{T}$, Root $\mathrm{R}$ : Complement factor $\mathrm{H}$ or a related protein is a marker for transitional cell cancer of the bladder. ClinCancer Res 1998, 4(10):2511-20
4. Heicappell R, Wettig IC, Schostak M, et al: Quantitative detection of human complement factor $\mathrm{H}$-related protein in transitional cell carcinoma of the urinary bladder. Eur Urol 1999, 35(1):81-7.

5. Thomas $L$, Leyh $H$, Marberger $M$, et al: Multicenter trial of the quantitative BTA TRAK assay in the detection of bladder cancer. Clin Chem 1999, 45:472-7.

6. Oge O, Kozaci D, Gemalmaz H: The BTA stat test is nonspecific for hematuria: an experimental hematuria model. J Urol 2002, 167(3):1318-9. discussion 1319-20.

7. Soloway MS, Briggman V, Carpinito GA, Chodak GW, Church PA, Lamm DL, Lange P, Messing E, Pasciak RM, Reservitz GB, Rukstalis DB, Sarosdy MF, Stadler WM, Thiel RP, Hayden CL: Use of a new tumor marker, urinary NMP22, in the detection of occult or rapidly recurring transitional cell carcinoma of the urinary tract following surgical treatment. J Urol 1996, 156(2 Pt 1):363-7.

8. Grossman HB, Messing E, Soloway M, Tomera K, Katz G, Berger Y, Shen Y: Detection of bladder cancer using a point-of-care proteomic assay. JAMA 2005, 293(7):810-6.

9. Sözen S, Biri H, Sinik Z, Küpeli B, Alkibay T, Bozkirli I: Comparison of the nuclear matrix protein 22 with voided urine cytology and BTA stat test in the diagnosis of transitional cell carcinoma of the bladder. Eur Urol 1999, 36(3):225-9.

10. Lotan Y, Shariat SF: NMP22 Study Group. Impact of risk factors on the performance of the nuclear matrix protein 22 point-of-care test for bladder cancer detection. BJU Int 2008, 101(11):1362-7. Epub 2008 Feb 18.

11. Atsü N, Ekici S, Oge OO, Ergen A, Hasçelik G, Ozen H: False-positive results of the NMP22 test due to hematuria. J Urol 2002, 167(2 Pt 1):555-8.

12. Nickerson J: Experimental observations of a nuclear matrix. J Cell Sci 2001, 114(Pt 3):463-74.

13. Nickerson JA: Nuclear dreams: the malignant alteration of nuclear architecture. J Cell Biochem 1998, 70(2):172-80.

14. Yang CH, Lambie EJ, Snyder M: NuMa an unusually long coiled coil protein in the mammalian nucleus. J Cell Biol 1992, 116:1303.

15. Uhlen M, Bjorling E, Agaton C, Szigyarto CA, et al: A human protein atlas for normal and cancer tissues based on antibody proteomics. Mol Cell Proteomics 2005, 4(12):1920-32.

16. Todenhöfer T, Hennenlotter J, Kühs U, Tews V, Gakis G, Aufderklamm S, Stenzl A, Schwentner C: Influence of urinary tract instrumentation and inflammation on the performance of urine markers for the detection of bladder cancer. Urology 2012, 79(3):620-4

17. Todenhöfer T, Hennenlotter J, Tews V, Gakis G, Aufderklamm S, Kuehs U, Stenzl A, Schwentner C: Impact of different grades of microscopic hematuria on the performance of urine-based markers for the detection of urothelial carcinoma. UrolOncol 2011, Epub ahead of print.

18. Huber S, Schwentner C, Taeger D, Pesch B, Nasterlack M, Leng G, Mayer T, Gawrych K, Bonberg N, Pelster M, Johnen G, Bontrup H, Wellhäußer H, Bierfreund HG, Wiens C, Bayer C, Eberle F, Scheuermann B, Kluckert M, Feil G, Brüning T, Stenzl A: UroScreen Study Group. Nuclear matrix protein-22: a prospective evaluation in a population at risk for bladder cancer. Results from the UroScreen study. BJU Int 2012, 110(5):699-708.

19. Todenhöfer T, Hennenlotter J, Witstruk M, Gakis G, Aufderklamm S, Kuehs U, Stenzl A, Schwentner C: Influence of renal excretory function on the performance of urine based markers to detect bladder cancer. J Urol 2012, 187(1):68-73.

20. Boman $\mathrm{H}$, Hedelin $\mathrm{H}$, Holmäng S: Four bladder tumor markers have a disappointingly low sensitivity for small size and low grade recurrence. J Urol 2002, 167(1):80-3.

doi:10.1186/1471-2490-12-23

Cite this article as: Miyake et al:: Influencing factors on the NMP-22 urine assay: an experimental model. BMC Urology 2012 12:23. 